\title{
Review of Relire Menandre
}

\section{Citation}

Thomas, Richard F. 1992. Review of Relire Menandre, by Eric Handley and Andre Hurst. Classical Philology 87(2): 164-167.

\section{Published Version}

doi:10.1086/367301

\section{Permanent link}

http://nrs.harvard.edu/urn-3:HUL.InstRepos:3778255

\section{Terms of Use}

This article was downloaded from Harvard University's DASH repository, and is made available under the terms and conditions applicable to Other Posted Material, as set forth at http:// nrs.harvard.edu/urn-3:HUL.InstRepos:dash.current.terms-of-use\#LAA

\section{Share Your Story}

The Harvard community has made this article openly available.

Please share how this access benefits you. Submit a story.

Accessibility 
P. suggests that its poet likewise gains freedom over inherited material to shape and control his narrative. These conclusions, arrived at by untraditional means, nevertheless command our assent; readers must decide for themselves whether the ends justify the means.

P.'s provocative reading of the Odyssey is intended to stimulate dialogue. If one may extrapolate from his dialectic model, one may guess that $\mathrm{P}$. analogously regards semiotics as the centrifugal voice that liberates from the authoritative discourse of philology. There remains, however, a middle ground, one that Bakhtin calls "internally persuasive discourse."

Internally persuasive discourse-as opposed to one that is externally authoritative-is, as it is affirmed through assimilation, tightly interwoven with "one's own word." In the everyday rounds of our consciousness, the internally persuasive word is half-ours and half-someone else's. Its creativity and productiveness consists precisely in the fact that such a word awakens new and independent words from within, and does not remain in an isolated and static condition. It is not so much interpreted by us as it is further, that is, freely, developed, applied to new material, new conditions; it enters into interanimating relationships with new contexts. More than that, it enters into an intense interaction, a struggle with other internally persuasive discourses. ${ }^{1}$

Jenny Strauss Clay University of Virginia

1. M. Bakhtin, "Discourse in the Novel," in The Dialogic Imagination, trans. C. Emerson and M. Holquist (Austin, 1981), pp. 345-46.

Relire Ménandre. Edited by ERIC Handley and AndRÉ HuRst. Recherches et rencontres: Publications de la Faculté des lettres de Genève. Genève: Libraire Droz S.A., 1990. Pp. 187.

The present volume is the result of a conference marking the thirtieth anniversary of the Geneva publication of the Bodmer Dyskolos, and held in Geneva (p. 12, "le lieu du crime!") in the fall of 1988. Discussion is recorded at the end, conveniently reorganized under themes, rather than keyed to each of the papers. The authors are all acknowledged Menandrians, and their combined contribution represents a real advance in our appreciation of the reputation of Menander, secure in antiquity, but largely unverifiable in modern times before the appearance of the Cairo and Bodmer codices. Much Menandrian scholarship of this century, understandably enough, has been directed toward smaller details-papyrological, editorial, and the like - and the present volume is particularly welcome in that the essays are all concerned with larger questions of Menander's literary art.

The first of the five essays, by H.-D. Blume ("Der Codex Bodmer und unserer Kenntnis der griechische Komödie"), is in large part synthetic, but no less valuable for being so, since it draws together a number of disparate contributions from the last few decades. He begins by looking at the Bodmer Menander in relation to Old Comedy, tracing the diminution in phenomena such as obscenity (reserved, with 
the exception of Smikrines at Epit. 647 and frag. 7, mainly for slaves, hetaerae, and the like), invective (restricted and harmless for the most part in that it is chiefly directed at figures such as parasites, such as Chairephon and Androkles in the Samia), the role of the chorus, already apparent in late Aristophanes (this is by now a truism, the one fact that everyone knows about Menander!), musical complexity, and aspects of performance, again already under way, for instance in the parody of new music, in the Birds. These particular lines of inquiry might fruitfully be followed in the case of other post-fifth-century genres. In a second part he applies these general principles to the Dyskolos, focusing on three areas: audience involvement and the dropping of dramatic fictions (again already observable for instance in Euripides), individuality and realism in style and diction (the basis of much of Menander's reputation), and the more regular imposition (developed from tragedy rather than Old Comedy) of a set structure, a contribution that is of great importance for subsequent European drama-although, as two members of the group note in the discussion (p. 149), we should perhaps not see Menander as rigidly imposing self-contained dramatic sections by means of these choral interludes.

P. G. McC. Brown's contribution on endings is somewhat at a disadvantage in that the topic has already been treated by other scholars, chiefly Anderson, Holzberg, and Hunter. With regard to the endings of Dyskolos and Samia Brown does modify Holzberg's claim that the action of Menandrian drama tends to be complete by the end of the fourth act, and the suggestion that we should not be overly schematic in our attitude to endings is well taken, even if the demonstration of the differences between these two endings (pp. 46-48) is a little labored. The bulk of the piece is concerned with the ending of Terence's Eunuchus and its possible relationship to Menander's Eunouchos. Although similarities are detected between Terence and elements of Aspis and Epitrepontes, we are here in a preBodmer, and even pre-Cairo, state of speculation, as Brown well realizes. Apart from useful detailed discussion, this offering demonstrates the extent to which, even with the new Menander, we are still often very much in the dark about the art of his comedy.

We move from endings to beginnings with N. Zagagi's fine essay on "Divine Interventions and Human Agents in Menander." In essence this is a study of Aspis, Perikeiromene, (the best I have read, both in general terms and specifically in tracing the movement from ignorance-emblemized by the prologist Agnoiato knowledge), and Dyskolos, and of the relevance of the prologues (by Tyche, Agnoia, and Pan, respectively) to the larger action of the plays. In each case Zagagi is convincing in arguing (now with the help of evidence) against Leo's earlier assumption that the prologues were ornamental in nature: even if every detail of the action is not anticipated in these prologues (for instance Pan does not explicitly mention the punishment of Knemon), such details do follow ultimately from, and are causally linked to, the events set in motion by the divinities (in the case of the Dyskolos, Sostratos' falling in love with Knemon's daughter under Pan's influence). Menander emerges in these pages as depicting a divinity that functions on a much more rationalistic and real level than is the case with Aristophanes. While this does not surprise, it is good to have such a lucid demonstration of the fact. Perhaps more than the others this contribution shows how the 
Bodmer material specifically has significantly advanced our understanding of the art of Menander, and to that extent at any rate it is one of the most successful.

The same may be said of A. Hurst's offering ("Ménandre et la tragédie"). It begins with a useful bibliographical survey of this central topic, which in recent years is beginning to be viewed as part of the larger question of influence and the relationship of poets to their models. Hurst rightly opts for the more Bloomian (my word, not his) view best put forward in R. Hunter's book, of Menander as "exploiter" of, rather than simply "debtor" to, tragedy. He then proceeds to a study of Menander's use of tragedy in three areas (tragic language, reference to actual tragedies, ordering of action in the manner of tragedy), chiefly in the famous instances from Dyskolos, Aspis, and Samia, but also from other, more fragmentary contexts. In general Hurst rightly rejects the more passive notion of tragedy somehow imbuing and elevating the Menandrian world, and favors a more polemical use, for instance in act 3 of the Aspis, where we know the reality (nontragic), and therefore view the quoting of high tragic maxims as false and even as buffoonery, all of which suggests a post-Aristotelian claim for comedy as the genre closer to real life. At the same time, various Menandrian features borrowed from tragedy (the action generally confined to a single day, the temporal coinci-

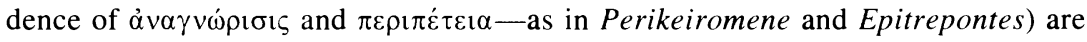
to be seen as appropriations to comedy of those very features in which tragedy's verisimilitude lies. Here Menander approaches the Hellenistic poets in his subversive stance toward his tradition-a proposition that will not find favor with those for whom Menander is simply a final Attic gasp, to be kept comfortably separate from the Alexandrians. Hurst is however rightly cautious in not necessarily making Menander too revolutionary in this development, given the huge gaps in our knowledge of fourth-century drama, and considering the prior existence of such texts as Antiphanes' Poiesis.

The final chapter (E. Handley's "The Bodmer Menander and the Comic Fragments") takes a step back and asks what we have ultimately learned from the Bodmer codex - not just what we have learned about the art of Menander, but also how perilous the ground is, particularly with those plays which remain in a fragmentary state. For instance, three of Körte's twelve fragments (pre-Bodmer) of the Dyskolos - 25 percent that is-are bogus, while a comparison of Dyskolos 797 812 and the "same" sixteen lines preserved by Stobaeus (Dysk. frag. 116 Kö.) is a disquieting experience. On the more positive side Handley then shows how much the Bodmer codex (and the Cairo) have taught us about Menander-about his style, his use of formulas, his structural conventions. There are two final sections: one presents an unedited Oxyrhyncus fragment, "very possibly but not necessarily Karchedonios," and these pages capture in microcosm that unique excitement attending the appearance of new literary papyri-a continuing excitement that this conference largely celebrated. (Here we find hope that the process may continue, hope realized in an appendix by $\mathrm{W}$. Willis of a papyrus from Duke University which minimally augments twenty-three lines of the Bodmer Aspis.) The other is partly palliative, an exposition of just how much Menander ("considerably more than 160 pages" for the Cairo codex alone) made it to the fifth, even the sixth century or later, only to end up as binding material, packaging, or just in the rubbish 
dump. If these dumps continue to produce, it is volumes like the present one that will provide the basis for our evolving understanding of, and familiarity with, this elusive and surprising poet.

Richard F. Thomas

Harvard University

Callimachus: "Hecale." Edited with introduction and commentary by A. S. Hollis. Oxford: Clarendon Press; New York: Oxford University Press, 1990. Pp. xiii +401 .

Of the major fragmentary works of Callimachus, the Hecale remains the worst preserved and the least tractable. Papyrus discoveries in this century have revealed significant sections of the Aetia, and the entire structure of the last two books has been reconstructed with some confidence. Considerable portions of several of the Iambi survive entire, and the shape of the book as a whole is visible from the Diegeses. But of the Hecale, only nine papyri, including the Vienna tablet, survive, and few are of any size; the longest continuous legible passage is a mere nineteen lines long, and a one-paragraph summary, the misleading emphases of which are evident even from the exiguous remains of the text, can do little to help us understand the structure and purpose of a poem that may have been as long as 1,500 verses. The vast majority of the 179 fragments (including incerta) in A. S. Hollis's excellent new edition consist of single lines, and often of single words, preserved, frequently without any indication of authorship, in Suidas. Even the new papyri permit a relatively secure ordering of fewer than half the fragments.

Little remains of the Hecale, and little is written about it: other than Pfeiffer's great Callimachus edition of forty years ago, there has been no full study of the fragments since I. Kapp's 1915 edition. Even the important fragments preserved in POxy. 2376-77 (frags. 47-49 Hollis = SH 286-87) have received far less attention than the comparable papyri of the Aetia. And yet the importance of the poem is obvious: it was, in all probability, the first of that amorphous poetic form known as the epyllion, and as such had a direct influence on both Hellenistic and Roman literature; many of its features - the poverty of Hecale herself, the early exploits of the youthful hero, the elliptical narrative, the extensive use of speeches, the aetiological conclusion-became poetic commonplaces; and it was imitated or adapted, as H.'s valuable index of such allusions makes clear, in extant poems ranging from Catullus 64 to Ovid's Metamorphoses to Nonnus. The appearance of H.'s thorough and careful edition of these meager remains, therefore, is all the more welcome.

The actual text of the fragments as presented by $\mathrm{H}$. is little changed from Pfeiffer's edition (or, where relevant, the Supplementum Hellenisticum). There are only two new fragments (6 and 85), of which the latter contributes a new verse, the former eight letters. Perhaps more important than these additions are ten previously ignored poetic citations from Suidas which $\mathrm{H}$. adduces in his appendix 5 , most of which probably belong in the text itself. $\mathrm{H}$. has made few changes in the text of the fragments: there are changes of accent, word division, orthography, or 